\title{
TREES AND THE RED-TAILED HAWK IN SOUTHERN SASKATCHEWAN
}

C. STUART HOUSTON, 863 University Drive, Saskatoon, Saskatchewan S7N 0J8 and MARC J. BECHARD, Department of Biological Sciences, Marshall University, Huntington, West Virginia. 25701

The Red-tailed Hawk is one of North America's most widely distributed raptors. Over the past 100 years, it has expanded its range and replaced the Redshouldered Hawk in much of eastern North America and it has usurped the territories of Swainson's and Ferruginous Hawks in parts of the West. ${ }^{4} 5$ In southern Saskatchewan, these last two species were common when the northern Great Plains were first settled, and the Red-tailed Hawk was relatively uncommon. Since then, both Ferruginous and Swainson's Hawks have declined and the Redtailed Hawk has spread and increased greatly in numbers. The spread of the Red-tailed Hawk here appears to be related to suppression of the almost annual range fires that kept the prairie treeless. By stopping fires, settlers started a gradual recolonization by trees in grasslands throughout North America. ${ }^{35}$ In southern Saskatchewan, many areas of once-open prairie gradually began to be dotted with clumps or bluffs of aspen poplar. Because the Red-tailed Hawk is a woodland species that nests at the edges of open areas, the increase in trees has favored the Red-tail and contributed to its local increase in the recent past. $^{2443}$

The accounts of early explorers and fur traders give a picture of the native prairie as a treeless expanse maintained by recurring range fires. For example, in 1820, west of Prince Albert at what is now Lily Plain, John Franklin noted: "A

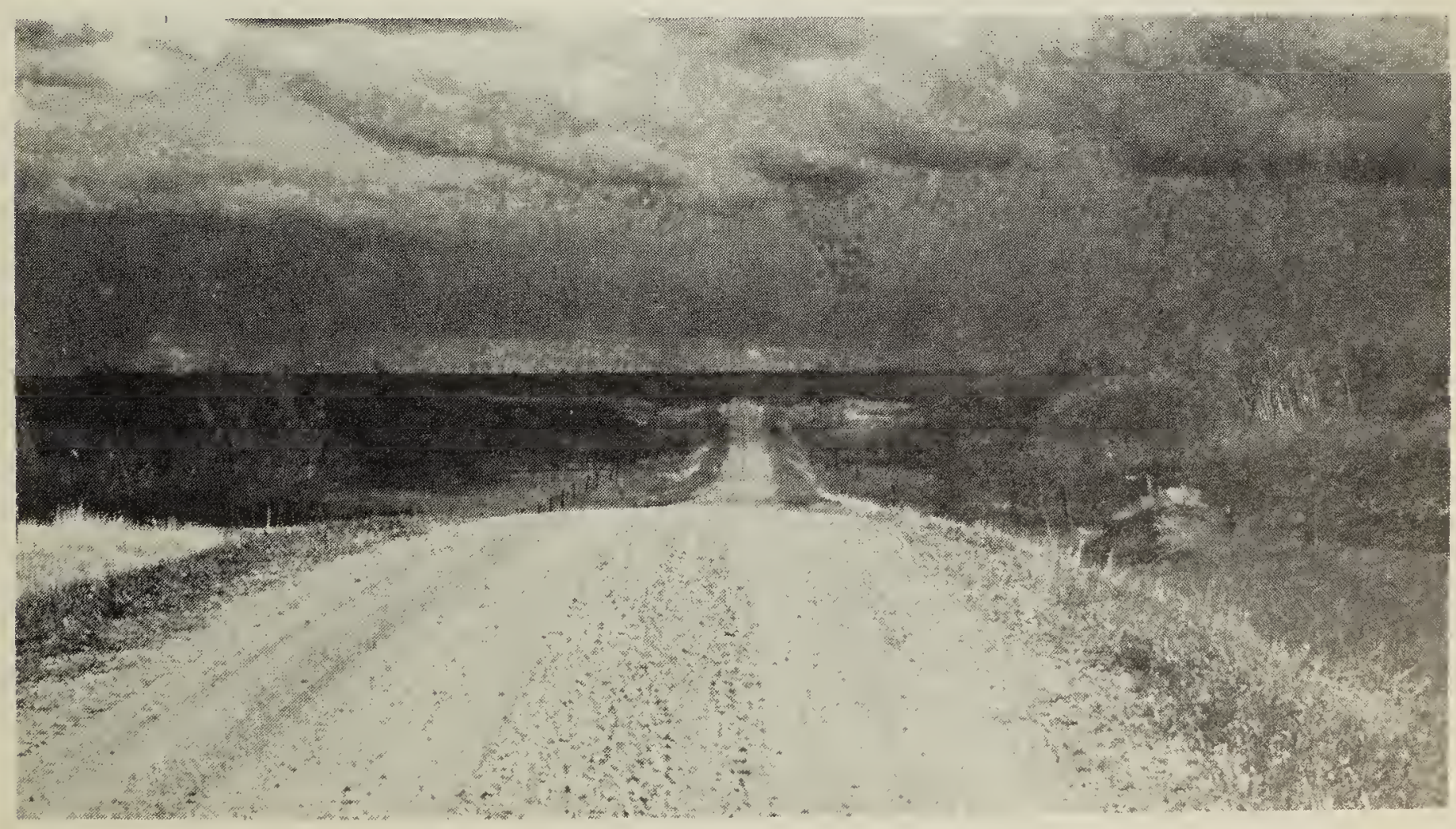


long track on the south shore ... is destitute of any thing like a tree, and the opposite bank has only stunted willows."10 As he continued along the North Saskatchewan River, Franklin described the land extending south and west, beginning at a point 20 miles northeast of Carlton as "the barren grounds." He noted that both banks were now bare of trees and that "vast plains ... afford excellent pasturage for the buffalo."10 John Richardson called the area between the north and south branches of the Saskatchewan River, "the Plains of the Saskatchewan," and only east of Carlton were the plains "beautifully ornamented by numerous small clumps of aspens, that gave a rich picturesque effect to the landscape, which I have never seen equalled even in an English park." 32 Even north of the North Saskatchewan River, on the trail to Green Lake from the river opposite Fort Carlton, there was a 16-mile stretch of treeless plain that was "an unvarying level, destitute of wood, except for one small cluster of willows."10

In 1872, George M. Grant's map showed that the Touchwood Hills, north of the Qu'Appelle River valley, were wooded; to the east, the Little Touchwood Hills, now known as the Beaver Hills, were "partially wooded" with "Aspen Poplars, Birch \& Willows forming artificial looking clumps, giving the country a rich Park-like aspect." However, in the Qu'Appelle valley itself there was then "very little timber" and "the plains in the vicinity are bare." John Macoun in 1883 confirmed the treelessness of the area in his statement: "That part of the prairie lying west of Moose Mountain, and a line connecting it with the Touchwood Hills, may be said to be wholly without wood, between the Boundary and lat. $52^{\circ}$ north. Wood Mountain and the Cypress Hills, together with the narrow river valleys, are the only exceptions."27

Dominion Lands Survey township maps of the 1880s provide further details concerning the proportions of grassland, woodland, and marsh in the decade immediately before appreciable settlement in southern Saskatchewan began. This material has been summarized and mapped by Archibold and Wilson. ${ }^{1}$ It shows that only a few townships in the Touchwood Hills, Beaver Hills, and Moose Mountains then had $45 \%$ or more wooded area. Most of the area was open grassland (Figure 1), though aspen roots were present throughout what is now "aspen parkland" (Figure 2).

As for the range fires, we know that at Fort Carlton fires broke out almost annually. ${ }^{41}$ John Palliser in 1857 commented that "a spark from a pipe may be sufficient to set 200 square miles of prairie in a blaze. The Indians are very careless .... and frequently fire the prairie for the most trivial reasons; frequently for signals to telegraph to one another concerning a successful horsestealing exploit or in order to proclaim the safe return of a war party. The disastrous effects of these fires consist principally in denuding the land of all useful trees." ${ }^{39}$ In 1858, Palliser continued: "Thus large tracts of country now prairie lands have at one time grown valuable forests, and their present absence is the result of the repeated ravages of fire." ${ }^{39}$

Henry Youle Hind reported a massive fire in September 1857, which covered an area "one thousand miles in length and several hundreds in breadth ... from the 49th parallel to the 53rd, and from the 98th to the 108th degree of longitude." 14 Near Oak Lake in southwestern Manitoba, Hind was more specific. There, he recorded that "the annual fires prevent the willows and aspens from covering the country, which they would undoubtedly do until replaced by other species, if not destroyed to within a few inches of the root every time the fire sweeps over them." 14 


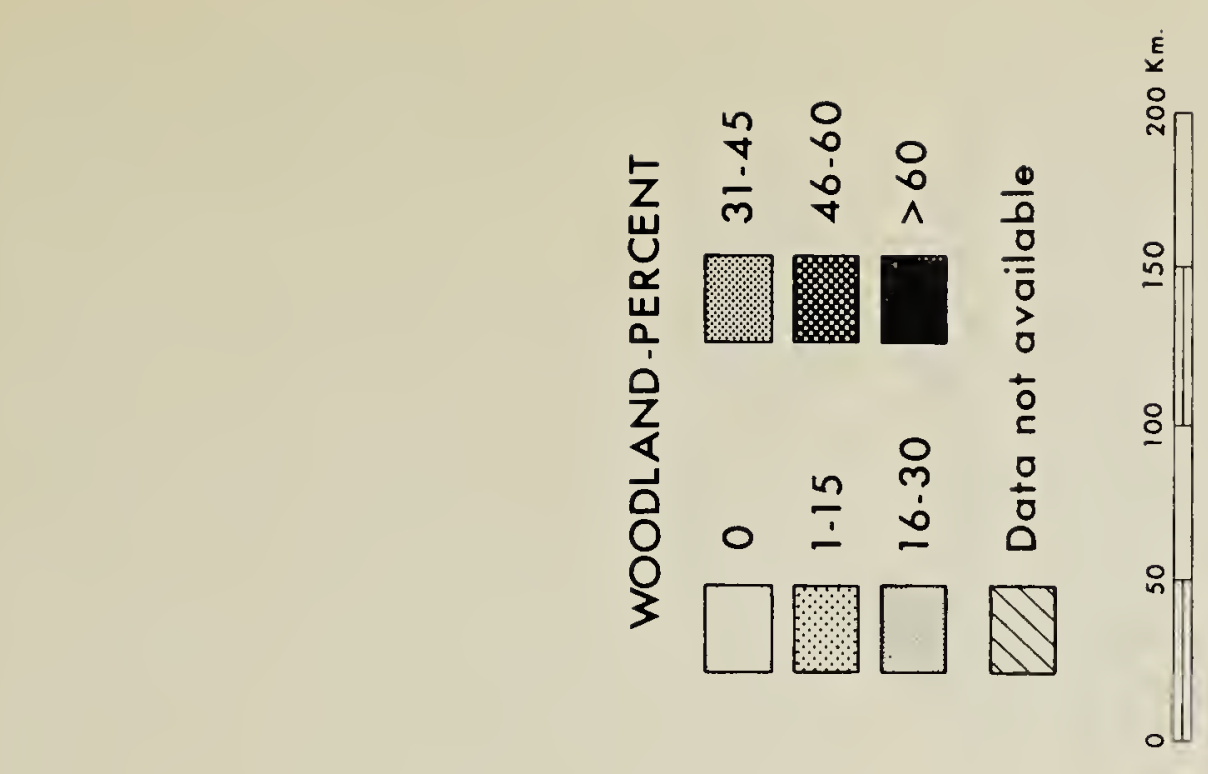

$e_{i-1}^{-1}$

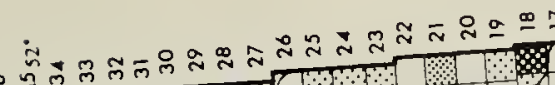

$\stackrel{m}{\simeq}=0 \infty$

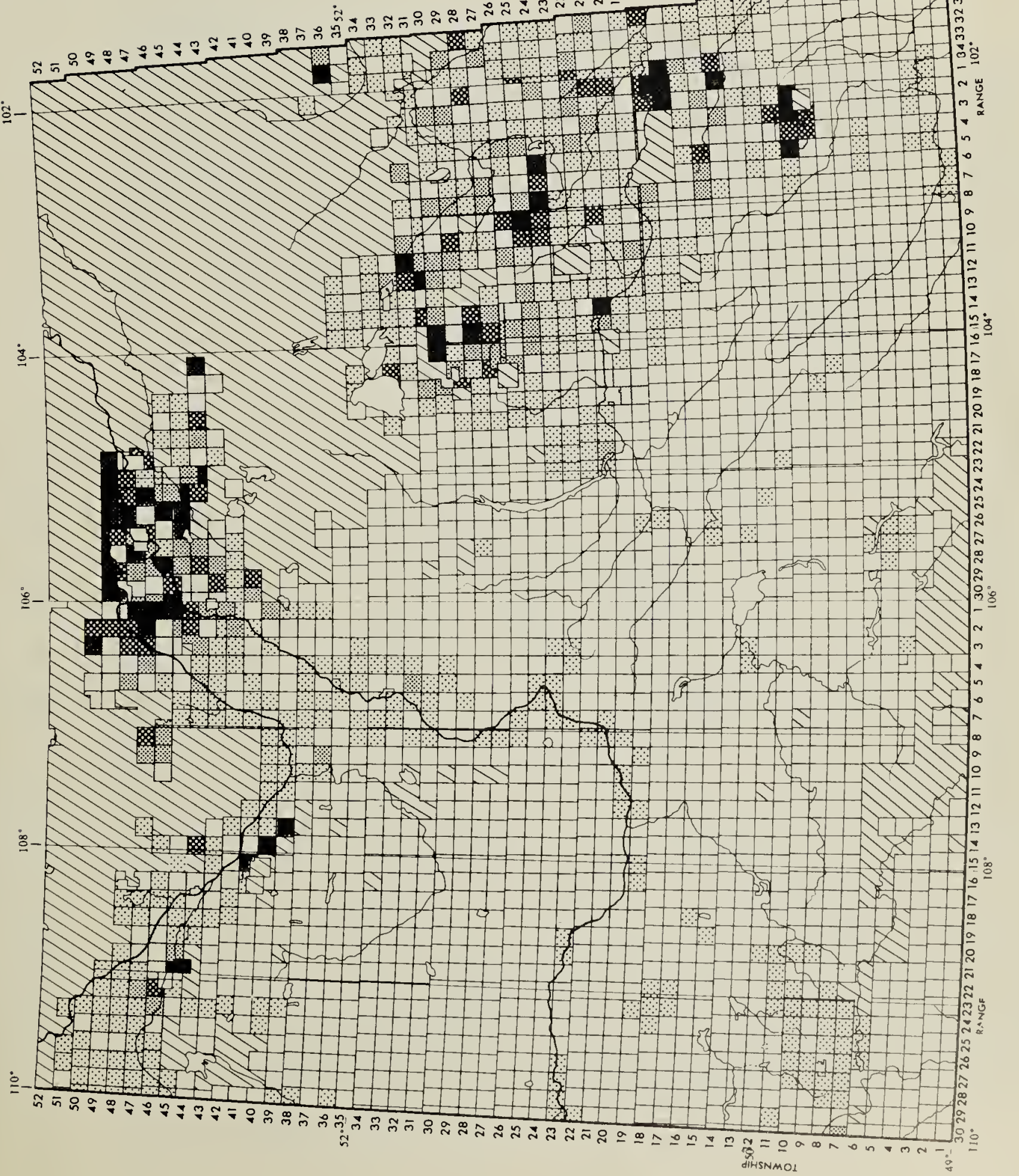




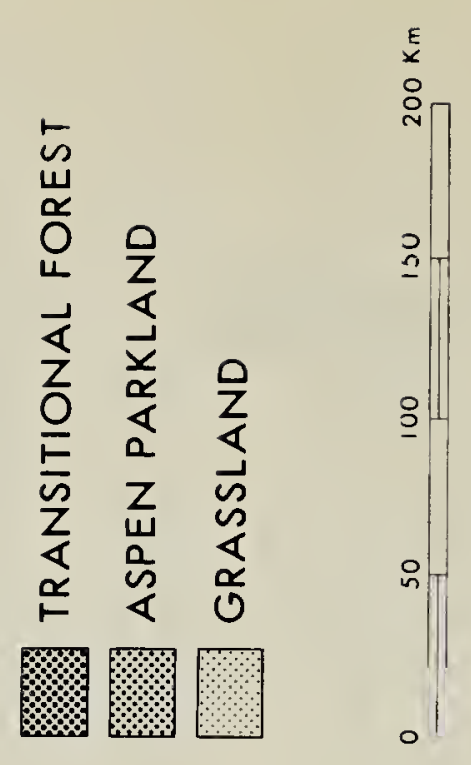

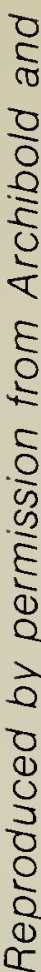

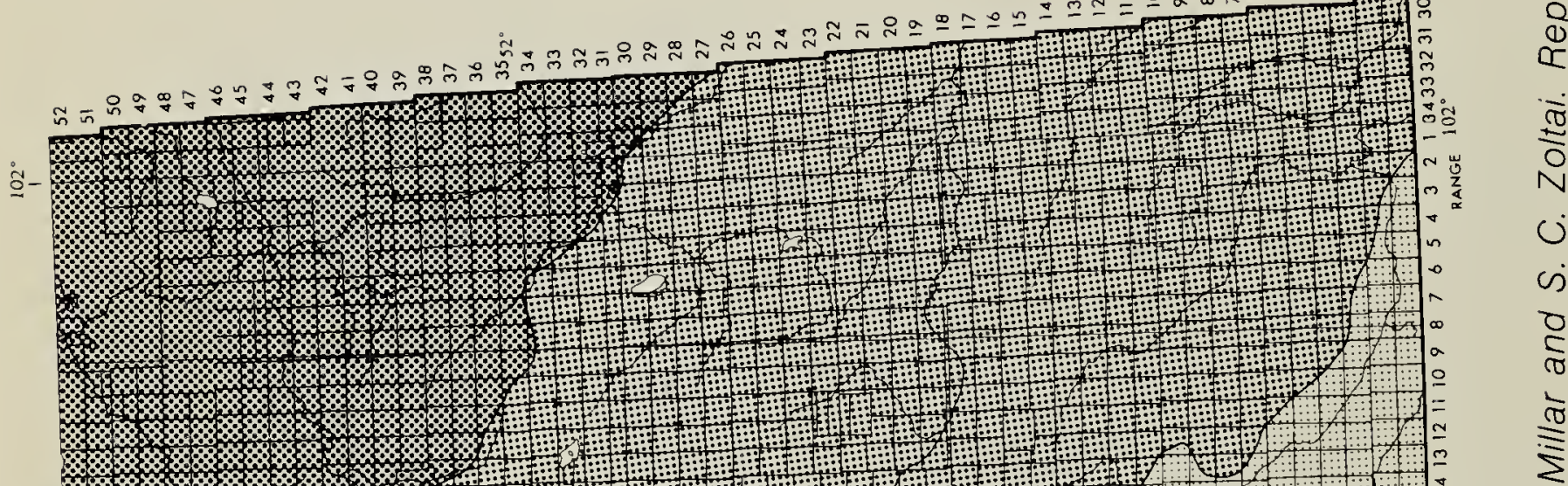

I

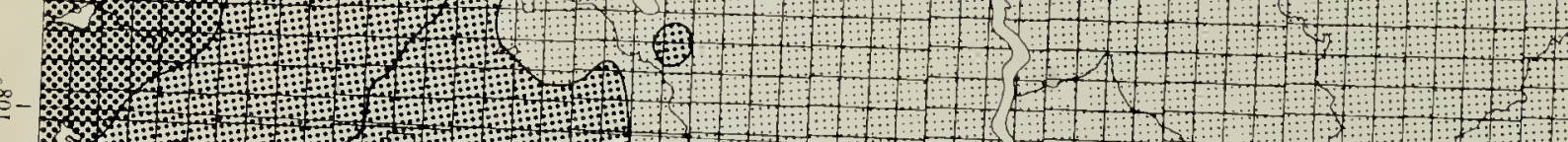

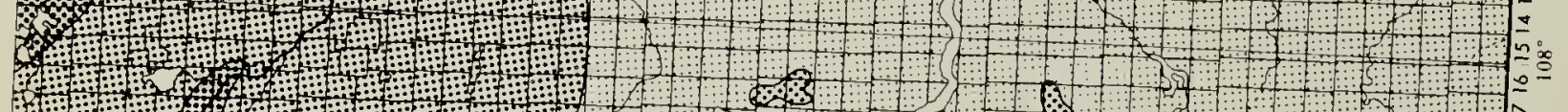

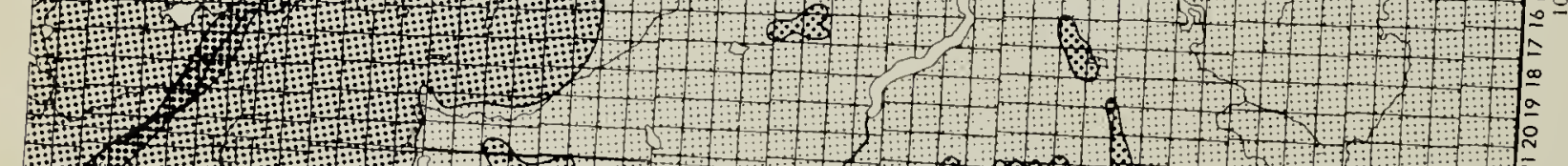


Ernest Thompson Seton arrived at Carberry, Manitoba in 1882 when settlement was first beginning. He was fascinated by the recovery potential of aspen after a couple of years without fires: "If a piece of the prairie, almost anywhere, be protected for two consecutive years it will be found covered with a growth of poplars and willows." ${ }^{37}$ While visiting Seton from England, Robert Miller Christy became interested in the prairie and later wrote a long article entitled "Why are the prairies treeless?" In it, he noted that "growth is slow and destruction by fire is swift... from what I have seen and heard, I imiagine that by far the larger portion of the whole area of the prairies gets burned over annually ... trees still grow on the prairies on spots that are to some extent protected from the fires; and that, over large portions of the prairies, young trees spring up annually, only to be at once burned... These trees have great vitality in their roots, and repeatedly send up fresh shoots after the annual fires."

Christy quoted a letter written by Robert Bell, then the director of the Geological Survey of Canada: "The rapidity with which some tracts between Prairie Portage and Fort Ellice were stated to have been converted from forest to prairie, is almost incredible." Regarding the area south of Fort Ellice, along the present ManitobaSaskatchewan boundary, Bell added: "The aspens of that region burn much more readily than does the wood of the same tree in Ontario and Quebec, and the portions which escape total destruction by fire rot and disappear in the course of one or two years."7

With the coming of settlement, the frequency of range fires at first increased. Sparks from steam locomotives became a major hazard. While taking the train in July 1894 from Crane Lake Station, John Macoun noted that "the grass was so dry on the prairie that I noticed eight fires starting from the sparks from the engine before we reached Swift Current." ${ }^{28}$ In 1893, one fire extended northeastward from Yellow Grass Marsh for 100 miles and measured 15 miles across. In July 1894 , another fire started near Swift Current and swept southeastwards over an area estimated at 6,000 square miles. ${ }^{32}$ Natural causes of fire, especially lightning, continued as a threat.$^{34}$ Somewhat paradoxically, the dry sandhills offered some protection from fire and trees thrived in sand south of Carberry and near the present site of Elbow. ${ }^{28} 37$

As land was ploughed and as road allowances began to be graded, the risk of extensive fires diminished. Farmers who made furrows up the road allowance as fire guards were relieved of a portion of their taxes. Nevertheless it was not until the 1910s and 1920s that the aspen roots, present throughout the present parkland area, had a chance to grow. Proof of this can be obtained by looking at the early photographs in any one of the many local history books published in recent years, noting everywhere the virtual absence of natural aspen bluffs or of planted shelter belts in the early part of the century, and the gradual appearance of trees thereafter. In regards to the reappearance of aspen, there is "no indication of continuing invasion of the grassland zone; the increasing prominence of aspen ... is associated only with the interrupted growth of existing patches made possible by protection from fire."'

A consistent story has been obtained by interviews with old-timers. For example, in the Findlater-Dilke area, where there are now up to a dozen bluffs per quarter section $\left(.65 \mathrm{~km}^{2}\right)$, there were few trees near the turn of the century. When Charles Edwards settled in the Arm River valley in 1887, there were a few small aspen bluffs, but these were soon destroyed by fires. When Lewis Jones arrived in 1906 his land was without trees, but occasional stumps 
were encountered during ploughing. When Mark Young came in 1907, the only firewood he found was a few willows beside a slough. Henry McArton in 1907 had a few aspen in a nearby ravine. As late as 1950, Mrs. Anfinson could see a car coming from any direction, though within ten years the aspen "bluffs" were so tall and so thick that they impeded the view.

On the other side of Last Mountain Lake, at what Grant considered as the southwestern outreach of the Touchwood Hills, there were tall trees surviving on the high land known as "Last Mountain". To the north near Raymore, there were only a few small bluffs of burnt-over aspen when Charles Harris arrived in 1909.

Similarly, at Fielding, $70 \mathrm{~km}$ northwest of Saskatoon, Henry C. Baker (interview of 18 May 1971) described the appearance of the land when he arrived in 1912: "There were no trees on farmland anywhere to impede the view or even to use for firewood. There were only willows, burned out many times. Although there were cottonwood and balsam poplar suitable for lumber along the north bank of the North Saskatchewan River, we had to cross to the southwest bank in winter to get firewood, for only there were the slopes well-treed with aspen."

The Swainson's Hawk at this time was a common buteo on the open prairie, and the Ferruginous Hawk then nested as far north as Carlton, Quill Lakes and Yorkton. All evidence points to the Redtailed Hawk being rare on the open plains, even in migration, until about 1920. Although a few of the pale Krider's subspecies might then be seen as far north as Wakaw Lake, and Lake Lenore, the Red-tail was a regular

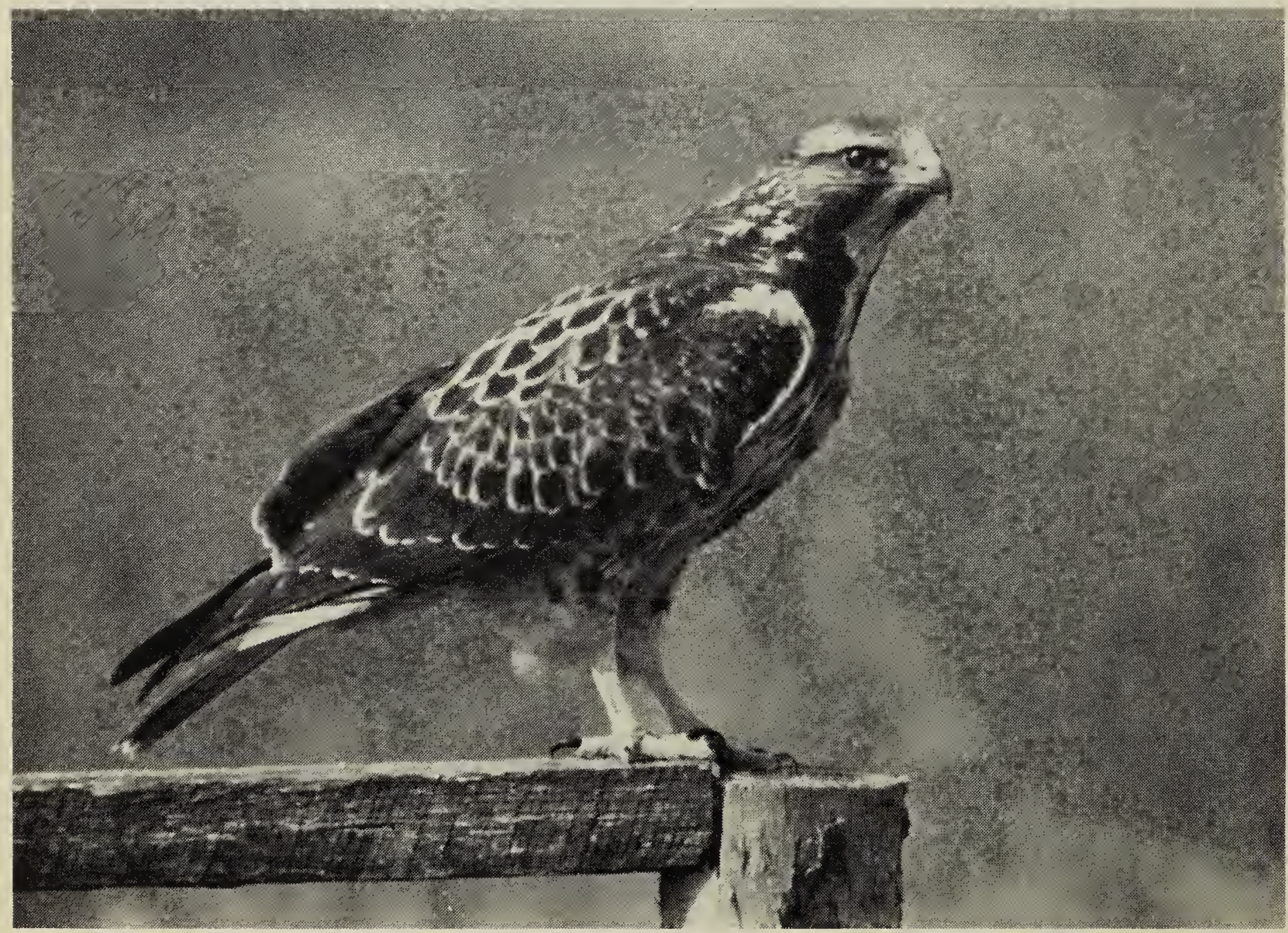


breeding species only in areas to the north of the plains, such as along the North Saskatchewan River, where trees grew to a substantial size. ${ }^{829}$ At Carlton, for example, Blakiston and Bourgeau found Swainson's Hawk to be "abundant" in 1858, but located only a single Red-tail nest. Similarly, Loring at nearby Wingard listed the Swainson's Hawk as "common and breeding" in 1895, but failed to list the Red-tail.." Farther east, at Prince Albert and St. Louis, Eugene Coubeaux in 1897 and Russell Congdon in 1902 found Red-tail nests to be more common; Congdon found 2 nests "placed near the top of tall trees growing only a few feet from the shore" of Wakaw Lake. Ernest Thompson Seton found the Red-tail "abundant" in the wooded Duck Mountains near present Runnymede in 1884, ${ }^{42}$ and it outnumbered the Swainson's Hawk near Raymore in 1909 (Charles Harris, pers. comm.) yet as late as $1924, \mathrm{H}$. H. Mitchell listed the Red-tail as "only fairly common, as observed through the south, Moose Mountain to Big River, ranging more sparingly northward."29

The unpublished records of early oologists confirm this distribution pattern. Only in heavily wooded areas of adjacent provinces, such as A.D. Henderson's haunts at Belvedere, Alberta and E. S. Norman's at Kalevala, Manitoba, were Red-tailed Hawk eggs collected regularly. In Saskatchewan, only 3 clutches are known to have been collected by oologists prior to 1900: William Spreadborough took one set of 3 eggs from a nest in a dead poplar near Indian Head on 31 May 1892 and Edward Arnold took sets at the Fishing Lakes near Fort Qu'Appelle on 8 June 1896 and 7 June 1898. Ferruginous Hawk nests then were easy to find, but North Dakota oologists such as George Withey had to make long excursions into the wooded portions of the Turtle Mountains or north to the Moose Mountains to collect a few treasured eggs of the Redtailed Hawk.
The Red-tailed Hawk was absent from the long lists of bird migration dates such as those kept by all four reporters of the Territorial Natural History Society from 1903 to 1909. Three of these observers were in or near the Qu'Appelle River valley: R. H. Carter at Muscow, George Lang at Indian Head and E. W. H. Trood at Cotham post office south of Dubuc; the fourth was Laurence B. Potter of Eastend. Of 191 raptor migration dates for 12 species, led by 39 dates for the Marsh Hawk, 36 for the American Kestrel and 29 for the Swainson's Hawk, there were no records for two of the most easily identified and most conspicuous migrants today, the Bald Eagle and the Red-tailed Hawk. Will C. Colt at Osler in 1893 had no listing for this species and, in a lifetime of reporting migration dates to the Biological Survey in Washington, D.C., Mrs. Esther Cates of McLean had no entries for the Red-tail. ${ }^{18} 23$

As late as 1932, a Carnegie Museum collecting trip to the Elbow-Davidsonimperial area, staffed by W. E. Clyde Todd, George Miksch Sutton and Albert C. Lloyd, failed in six weeks of intensive study to see a single Red-tailed Hawk. ${ }^{44} 45$ On the other hand, when C. G. Harrold made a 34-day collecting trip to Old Wives and Last Mountain Lakes in 1922, he found a remarkable scarcity of buteos, with a single sighting each of a Swainson's and a Ferruginous Hawk, yet he found a Red-tailed Hawk nest with one egg, 6 feet from the ground in a poplar, on 14 May. ${ }^{13}$

As aspen bluffs became more numerous and more mature, with larger and taller trees, Red-tailed Hawks began a gradual increase. In wooded coulees of the Qu'Appelle valley west of Fort Qu'Appelle, R. H. Carter first described the Red-tail as "rare," but beginning in 1923 he was able to band young in one to three nests during most years in the 1920s. ${ }^{15} 1617$ It was not until 1929 that George Lang listed the Redtail in his migration dates with the 
notation "moderately common" and by 1937 as "common" in migration. ${ }^{20}$ It was not until the late 1920s that H. H. Pittman could observe that the Wauchope-Redvers area of southern Saskatchewan was "rapidly becoming covered with little groups of trees or bluffs, and in these the Crows nest plentifully". ${ }^{31}$ Pittman made his first notation concerning Red-tailed Hawks in 1951 and found his first nest in 1955. ${ }^{19}$

In the late 1930s, J. H. Taylor recorded a nesting pair of Red-tails in the Wascana Creek valley north of Regina, but it was not until 1956 that the first nest was found at Buffalo Pound Lake north of Moose Jaw. ${ }^{325}$ At Bladworth, P. Lawrence Beckie found his first Red-tail nest ever in 1958, and had three pairs nesting in 1959 (pers comm.). At Dilke, J. Boswell Belcher reported the first nesting pairs about 1960 (letter of 16 July 1971). In the coulees of the South Saskatchewan River north of Main Centre, George Harder had the first resident pair on his ranch in 1968, and a pair nested in 1976, 1977 and 1978 (pers. comm.).

All available evidence indicates that the Red-tail has only recently become a breeding species in the East Block of the Cypress Hills. The resident naturalists of the hills, Laurence $B$. Potter, Spencer Pearse, Charles F. Holmes and Steve A. Mann, all failed to find evidence of nesting; Potter had three sightings in the fall of 1924 but listed it as "rare, not breeding." $21 \mathrm{~J}$. Dewey Soper's unpublished field notes listed a pair of Red-tails on Lower Battle Creek 18-20 June 1942 and W. Earl Godfrey saw one individual near Cypress Hills Provincial Park on 2 July $1948 .{ }^{38} 11$ The first nesting records are for 13 June 1976 at Ravenscrag Butte (three young banded by Lynn Oliphant, $P$. Thompson and R. Rafuse) and 21 June 1977, a nest with three young at "Jones Peak" west of Eastend (Michael A. Gollop, letter of 31 March 1983). Gollop feels that there might now be five pairs in the rather inaccessible treed coulees within $15 \mathrm{~km}$ of Eastend.

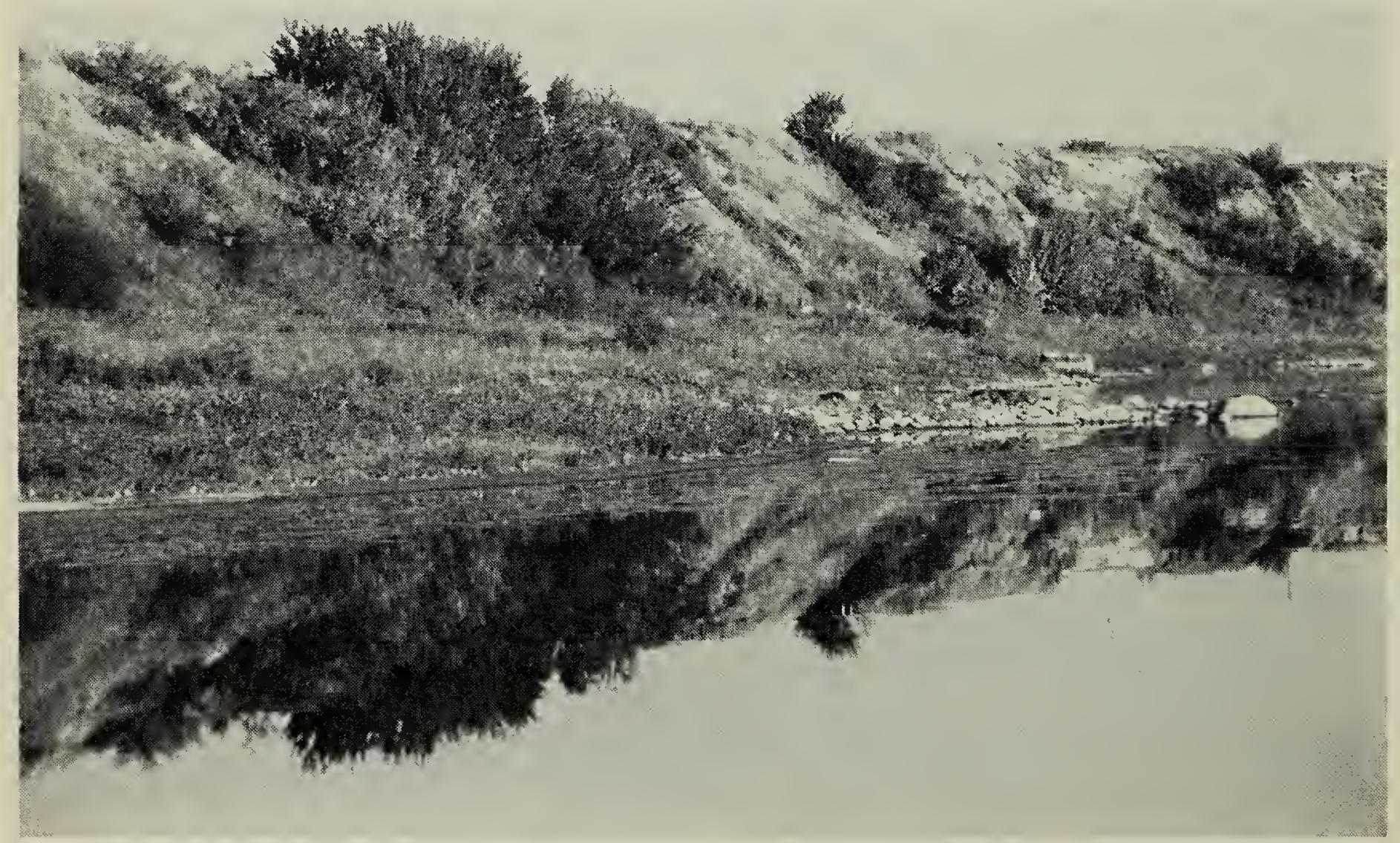


While there is little doubt of the spread of the Red-tailed Hawk in southern Saskatchewan, numerical data to measure the extent of the increase are difficult to obtain. At Carlton in 1939, Farley Mowat recorded 42 sightings of Swainson's Hawk, 37 of Red-tailed Hawk and 17 of Ferruginous Hawks, while in 1956 Houston sighted only 2 Swainson's, 33 Red-tailed Hawks and no Ferruginous Hawks. ${ }^{3024}$ At Yorkton, where in Houston's boyhood the Swainson's Hawk was the dominant buteo south of the city around the Rousay Lakes, Rokeby Marsh and Crescent Marsh areas where he worked for Ducks Unlimited, Adam Schmidt's survey of 1973 in the same area located 11 Redtailed Hawk nests but only a single Swainson's Hawk nest. ${ }^{36}$ Near Naicam, where the Swainson's Hawk actually increased to become the commonest buteo by the early 1940s, there was complete replacement by Red-tailed Hawks 20 years later (W. Yanchinski, pers. comm., 11 August 1971). Near Indian Head, the Red-tailed Hawk had replaced the Swainson's Hawk by 1969 when R. Lorne Scott banded 69 Redtailed nestlings. Today, in good parkland habitat near Yellow Creek, nesting Red-tails average about one pair per square mile $\left(2.6 \mathrm{~km}^{2}\right.$ ) (Houston, unpublished data). In migration, Redtailed Hawks appear to have increased greatly and in recent years from 500 to 2,500 have been counted flying over Indian Head during the peak day of spring migration. ${ }^{6}$

It seems probable that an ability to occupy edge habitats, and aggressive behaviour towards other buteos on the open side of the habitat gradient from forest to treeless prairie, has preadapted the Red-tailed Hawk for the semi-open tree-grassland mosaic that has developed with the cessation of range fires. It is "an extremely adaptable raptor, capable of efficiently utilizing a wide variety of habitat types." 26 A further extension of range of the Red-tail is not expected for as more and more aspen trees are bulldozed, we predict that the Red-tail will instead begin to decline. There is evidence that Red-tailed Hawk numbers may in fact have peaked about 1970 and that a decided decline may have already occurred in the Indian Head area (Lorne Scott, pers. comm.). ${ }^{6}$

The timing of the Red-tailed Hawk range expansion was similar to but slightly later than that of the Western Kingbird, though the latter species moved in from the south and west, not from the north and east. The Western Kingbird colonized the plains when trees reached a height of 6 or $7 \mathrm{~m}$, a process that took about 20 years. ${ }^{22}$ Since the Red-tailed Hawk requires trees with a height of about $10 \mathrm{~m}$, its expansion took somewhat longer, in the neighborhood of 30 years.

There are questions concerning the spread of the Red-tailed Hawk that remain unanswered. It is difficult, for example, to explain the near-total absence of migration records from the open plains before the 1920s. In the absence of suitable trees and especially before

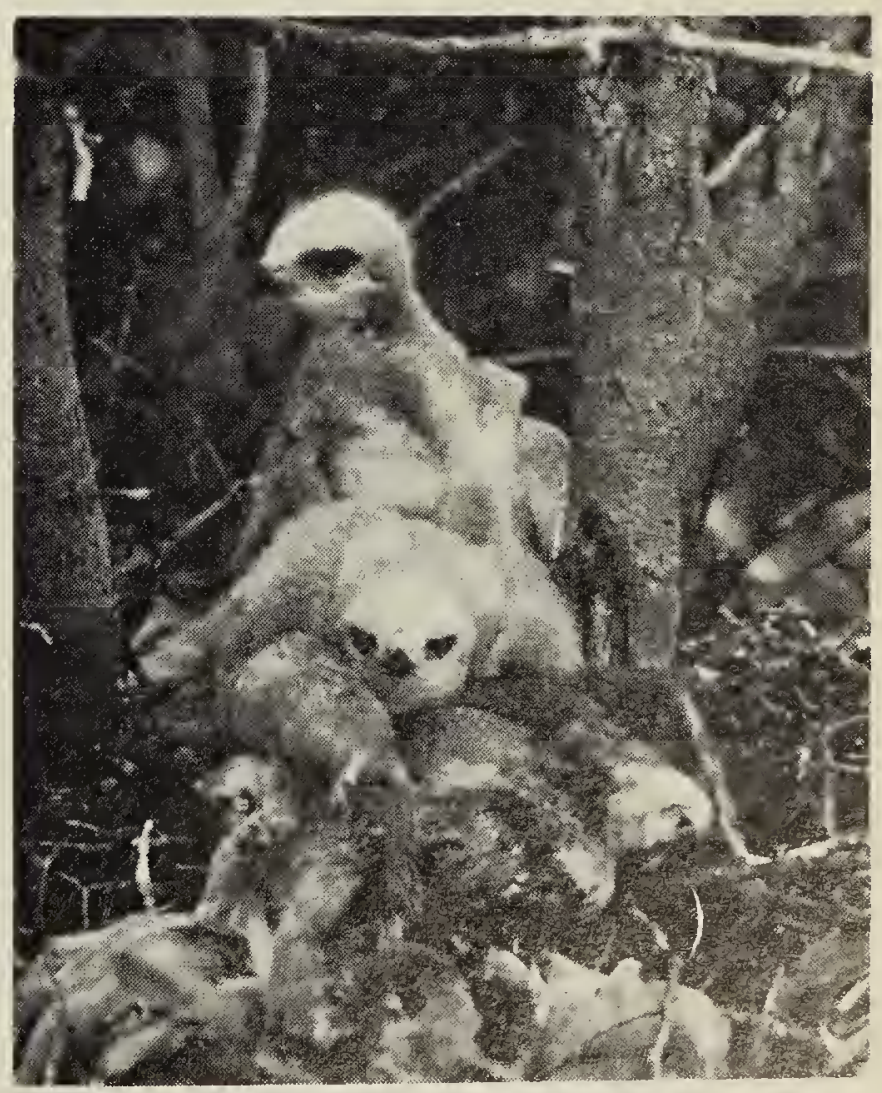

Nestling Red-tailed Hawks and Richardson's Ground Squirrels. 
telephone poles became widespread, did the Red-tailed Hawks simply fly high over - or around - the open plains? Did they fly so high that they could not be identified? Although the Red-tailed Hawk is now considered by birders as one of the easiest hawks to identify, showings its name when the sun shines on its distinctively coloured tail, it was nevertheless misidentified as a Roughlegged Hawk, by a few oologists. Such errors must be taken into account, but by no means destroy the general conclusion of this paper, for one of us has personally observed the spread and increase of the Red-tailed Hawk over 40 years, paralleling the increase in the number and size of aspen bluffs on the prairie.

\section{Acknowledgements}

We wish to thank O.W. Archibold and M. R. Wilson and the editors of the Canadian Journal of Botany for permission to reproduce Figures 1 and 2, which were figures 4 and 10 , respectively, in their superb study, "The natural vegetation of Saskatchewan prior to agricultural settlement," Can. J. Botany 58:2031-2042, 1980. We also wish to thank all the individual pioneers mentioned in our article, who provided their observations on trees and hawks in the early days. J. Bernard Gollop offered constructive criticism.

ARCHIBOLD, O. W. and M. R. WILSON. 1980. The natural vegetation of Saskatchewan prior to agricultural settlement. Can. J. Botany 58: 2031-2042.

${ }^{2}$ BEDNARZ, J. C. and J. J. DINSMORE. 1982. Nest-sites and habitat of Redshouldered and Red-tailed Hawks in lowa. Wilson Bulletin 94: 31-45.

${ }^{3}$ BELCHER, M. 1980. Birds of Regina, revised edition. Regina: Sask. Nat. Hist. Soc., Spec. Publ. 12151 pp.

${ }^{4}$ BOCK, C. E. and L. W. LEPTHIEN. 1976. Geographical ecology of the common species of Buteo and Parabuteo wintering in North America. Condor 78: 554557.
${ }^{5}$ BROWN, W. H. 1964. Population changes in Red-shouldered and Red-tailed Hawks. lowa Bird Life 34: 82-88.

${ }^{6}$ CALLIN, E. M. 1980. Birds of the Qu'Appelle, 1857-1979. Regina: Sask. Nat. Hist. Soc., Spec. Publ. 13, 168 pp.

7 CHRISTY, R. MILLER. 1892. Why are the prairies treeless? Proc. Royal Geographical Society 14: 78-100.

${ }^{8}$ CONGDON, R. T. 1903. Saskatchewan birds. Trans. Wisconsin Acad. 14: 569620.

${ }^{9}$ COUPLAND, R. T. and J. S. ROWE. 1969. Natural Vegetation of Saskatchewan, pp. 73-75 in: Richards, J. H. and K. I. Fung, Atlas of Saskatchewan. Saskatoon: University of Saskatchewan.

${ }^{10}$ FRANKLIN, JOHN. 1823. Narrative of a Journey to the Shores of the Polar Sea in the Years 1819, 20, 21 and 22. London: John Murray.

$"$ GODFREY, W. E. 1950. Birds of the Cypress Hills and Flotten Lake Regions, Saskatchewan. Ottawa: National Museum of Canada Bull. 120, 96 pp.

12 GRANT, GEORGE M. 1873. Ocean to Ocean. Sandford Fleming's Expedition through Canada in 1872. Toronto: James Campbell \& Son. Plate 19, opposite p. 109.

${ }^{13}$ HARROLD, C. G. 1933. Notes on the birds found at Lake Johnston and Last Mountain Lake, Saskatchewan, during April and May, 1922. Wilson Bull. 45:16-26.

${ }^{14}$ HIND, H.Y. 1860. Narrative of the ... Assiniboine and Saskatchewan exploring expedition of 1858. London: Longman, Green, Longman and Roberts, Vol. I, pp. 292, 294.

15 HOUSTON, C. S. 1945. Saskatchewan Bird Banders. No. 4. R. H. Carter, Jr. Blue Jay 3:37.

${ }^{16}$ HOUSTON, C.S. 1967. Recoveries of Red-tailed Hawks banded in Saskatchewan. Blue Jay 25:109-111.

${ }^{17}$ HOUSTON, C. S. 1968. Saskatchewan Bird Banders. No. 10. John R. Carter of Muscow. Blue Jay 26:118. 
${ }^{18}$ HOUSTON, C. S. 1970 . Will C. Colt's 1893 migration records for Osler, Saskatchewan. Blue Jay 28:7-10.

${ }^{19}$ HOUSTON, C. S. 1972. Harold Herbert Pittman, 1889-1972, a memorial tribute. Blue Jay 30:202-206.

${ }^{20}$ HOUSTON, C. S. 1978. George Lang pioneer ornithologist of Indian Head. Blue Jay 36:7-10.

${ }^{21}$ HOUSTON, C. S. 1979a. Four ranchernaturalists of the Cypress Hills, Saskatchewan. Blue Jay 37:9-19.

22 HOUSTON, C. S. 1979b. The spread of the Western Kingbird across the prairies. Blue Jay 37:149-157.

${ }^{23}$ HOUSTON, C. S. 1981. The Wemyss sisters: Saskatchewan's first lady birdwatchers, 1898-1940. Blue Jay 39:25-29.

${ }^{24}$ HOUSTON, C. S. and M. G. STREET. 1959. The Birds of the Saskatchewan River, Carlton to Cumberland. Regina: Sask. Nat. Hist. Soc., Spec. Publ. 2.

${ }^{25}$ KNIGHT, L. M. 1967. Birds of the Moose Jaw area. Moose Jaw: Moose Jaw Natural History Society. 73 pp.

${ }^{26}$ LUTTICH, S., D. H. RUSCH, E. C. MESLOW and L. B. KEITH. 1970. Ecology of Red-tailed Hawk predation in Alberta. Ecology 51:1920-203.

${ }^{27}$ MACOUN, J. 1883. Manitoba and the Great North-west. London: Thomas C. Jack. 687 pp.

${ }^{28}$ MACOUN, J. 1922. Autobiography of John Macoun, M.A., Canadian Explorer and Naturalist. Ottawa: Ottawa FieldNaturalists Club, 303 pp. [Reprinted 1979, Spec. Publ. 1 Ottawa FieldNaturalists Club, with new introduction by Richard Glover, editorial notes \& bibliographical essay by W. A. Waiser, pp. 307-335.

${ }^{29}$ MITCHELL, H.H. 1924. Birds of Saskatchewan. Can. Field-Nat. 38:101118.

${ }^{30}$ MOWAT, FARLEY. 1946. Unpublished notes May 8-30, Dundurn area; June 3July 14, Montreal Lake area; July $17-$ July 20, Yorkton area.

${ }^{31}$ PITTMAN, H. H. 1928. Mallards on the prairie. Bird-Lore 30:5-7.
${ }^{32}$ RABY, S. 1966. Prairie fires in the Northwest Saskatchewan History 19:81-99.

${ }^{33}$ RICHARDSON, J. and W. SWAINSON 1832. Fauna Boreali-Americana, Vol. II, the Birds. London: John Murray. 501 pp.

${ }^{34}$ ROWE, J. S. 1969. Lightning fires in Saskatchewan grassland. Can. Field-Nat. 83:317-324.

${ }^{35}$ SAUER, C. O. 1950. Grassland climax, fire and man. J. Range Management 3:1620.

${ }^{36}$ SCHMIDT, A. 1973. An ecological survey of the Yorkton wetland complex. Saskatchewan Dept. of Natural Resources, $105 \mathrm{pp}$. (unpublished).

${ }^{37}$ SETON, ERNEST E. T. 1883. Prairie Fires. pp. 491-492 in: Appendix 19, Manitoba Dept. of Agriculture and Statistics.

${ }^{38}$ SOPER, J. D. 1970. Unpublished field notes on the birds observed and collected in the province of Saskatchewan, Canada, in 1914, 1921, 1927 and from July 1937 to September 1947. Dept. of Zoology, U. of Alberta, Edmonton.

${ }^{39}$ SPRY, IRENE M. 1968. The Papers of the Palliser Expedition, 1857-1860. Toronto: Champlain Society. pp. 157, 231.

40 TERRITORIAL NATURAL HISTORY SOCIETY. Bird Migration Notes. Spring 1903, Spring and Fall 1904, Spring 1905, Spring 1906, Spring 1907, Spring 1908, Spring 1909. Printed by the Saskatchewan Dept. of Agriculture in their annual reports, and 1907-19081909 reprinted as a combined sheet.

41 THOMAS, GREGORY. 1977. Fire and the fur trade: the Saskatchewan district: 1790-1840. Beaver 308.2:32-39.

42 THOMPSON SETON, E. E. 1891. The Birds of Manitoba. Proc. U.S. Nat. Museum 13:457-643.

${ }^{43}$ TITUS, K., and J. A. MOSHER. 1981. Nest-site habitat selected by woodland hawks in the central Appalachians. Auk 98:270-281.

${ }^{44}$ TODD, W. E. C. 1932. Glimpses of prairie bird life. Carnegie Magazine 6:115-116.

${ }^{45}$ TODD, W. E. C. 1947. Notes on the birds of southern Saskatchewan. Ann. Carnegie Museum 30:383-421. 